\title{
ANALISIS EFEKTIVITAS PENGGUNAAN ANGGARAN SEBAGAI ALAT PENGENDALIAN BELANJA LANGSUNG PADA BIRO HUKUM PROVINSI SULAWESI UTARA
}

\author{
Rahmawaty M. Bumulo ${ }^{1}$, Linda Lambey ${ }^{2}$, Lidia M. Mawikere $^{3}$ \\ 1,2,3 Jurusan Akuntansi, Fakultas Ekonomi dan Bisnis, Universitas Sam Ratulangi, Jl.Kampus Bahu, Manado, \\ 95115, Indonesia \\ E-mail : marinabumulo@gmail.com
}

\begin{abstract}
Budget has an important role any organization both government and private organizations. Budget is a guideline for the actions that will be implemented by the government. It includes the transfers of expenditure and financing plans that measured in Rupiah. Those are arranged systematically in accordance to a certain classification over one period. Budget preparation should be planned in advance so that the programs and activities targeted by the organization can be achieved. This study was conducted with the aim to find out how the budget is made, how the effectiveness of budget use is as a means of controlling direct expenditure, what factors influence the budget absorption mismatch in the North Sulawesi Provincial Legal Bureau in 2015-2017.The analytical method used is descriptive analysis. The results of the research for budget preparation are in accordance with the applicable regulations, that the effectiveness level from the year 2015 to 2017 as a whole is in the effective category. By the year of 2015 the effectiveness of the direct expenditure budget utilization is at $96.33 \%$ (effective), which has the lowest budget absorption compared to the year 2016-2017. By the year of 2016 the effectiveness of the direct budget utilization is at $99.76 \%$ (effective), and by the year2017 the level of effectiveness is $99.70 \%$ (effective). Budget absorption mismatches occur because of budget savings the residual value of spending, the difference in market prices from the prices already budgeted by the Sulawesi Provincial Legal Bureau.
\end{abstract}

Keywords: Budgets, Effectiveness, Direct Expenditure

\section{PENDAHULUAN}

Untuk mewujudkan pelayanan publik kepada masyarakat, setiap tahunnya seluruh pemerintah daerah akan merencanakan, menyusun, dan melakukan seluruh kegiatan dan pendanaan yang sudah terangkum dalam rencana keuangan tahunan berupa Anggaran Pendapatan dan Belanja Daerah (Windari, 2015). Anggaran digunakan sebagai alat informasi dan meyakinkan legislatif bahwa tidak ada pemborosan dan korupsi bagi pemerintah dan Pemerintah juga bekerja secara efisien dan efektif (Siregar, 2017).

Penyusunan anggaran merupakan tahap yang penting bagi instansi pemerintah yaitu membantu pelaksanaan dalam menetapkan program/kegiatan dan memberikan gambaran mengenai besaran dana yang akan dianggarkan untuk melaksanakan program dan kegiatan tersebut sehingga dapat meminimalisir penyimpangan-penyimpangan. Anggaran dan Realisasi memiliki keterkaitan yang memberikan gambaran apakah suatu instansi dapat dikatakan efektif atau tidak dalam penyerapan anggaran dan pembiayaan atas terlaksana kegitan dari instansi tersebut selama satu tahun anggaran. Laporan Realisasi Anggaran (LRA) merupakan dokument yang bisa memberikan gambaran secara langsung secara langsung tentang besarnya penyerapan anggaran belanja dengan realisasinya yang bisa dinyatakan dalam bentuk nominal atau persentase (Windari, 2015).

Selama ini penggunaan anggaran pada Biro Hukum tidak dapat dihindarkan terjadinya ketidaksesuaian antara realisasi dengan anggaran yang telah direncanakan, 
sehingga perlu diketahui faktor-faktor yang menjadi penyebab ketidaksesuaian. Untuk itu, Biro Hukum membutuhkan suatu strategi dalam mengelola anggaran agar kinerja Biro Hukum menjadi lebih baik. Berdasarkan uraian di atas terlihat jelas bahwa penyusunan anggaran dan penggunaan anggaran mempunyai peranan yang begitu penting untuk lembaga pemerintah agar bisa mencapai tujuannya.

\section{TINJAUAN PUSTAKA}

Akuntansi. Hutauruk (2017 : 4) akuntansi adalah kumpulan teknik dan konsep yang digunakan sebagai alat pengukuran dan pelaporan informasi keuangan pada suatu perusahaan. Informasi akuntansi akan digunakan oleh pihak-pihak yang membutuhkan, seperti: karyawan, analisis keuangan, kreditor, manajer perusahaan, pemilik, pemerintah.

Akuntansi Sektor Publik. Akuntansi sektor publik menurut Sujarweni (2015 : 1) adalah aktivitas jasa yang terdiri dari mencatat, menggolongkan, dan melaporkan kejadian ekonomi yang dapat memberikan suatu informasi keuangan dan akan digunakan oleh pihakpihak yang berkepentingan tertentu agar bisa mengambil keputusan.

Anggaran Sektor Publik. Anggaran merupakan dokumen yang berisi penerimaan dan pengeluaran yang akan dicapai pada periode waktu tertentu dan menyertakan data masa lalu sebagai bentuk pengendalian dan penilaian kinerja yang disajikan dalam bentuk moneter (Halim dan Kusufi, 2014 : 48).

Fungsi Anggaran Sektor Publik. Haruman (2013 : 11) menyatakan bahwa anggaran sektor publik mempunyai beberapa fungsi utama yaitu sebagai berikut:

1. Anggaran berfungsi sebagai hasil akhir dari proses penyusunan rencana kerja.

2. Anggaran berfungsi sebagai aktivitas yang akan dilaksanakan pada periode yang akan datang.

3. Anggaran berfungsi sebagai alat komunikasi interen antara atasan dan bawahan yang menghubungkan berbagai unit kerja dan mekanisme kerja.

4. Anggaran berfungsi sebagai alat pengendali unit kerja.

5. Anggaran berfungsi sebagai alat untuk mendorong organisasi agar bisa bertindakan efektif dan efisien dalam mencapai visi organisasi.

6. Anggaran berfungsi sebagai instrumen politik.

7. Anggaran berfungsi sebagai instrumen kebijakan fiskal.

Pengendalian Anggaran. Siregar (2017 : 30) pengendalian anggaran sektor publik dapat dilakukan dengan empat cara, yaitu:

1. Membandingkan kinerja anggaran dengan realisasi.

2. Menghitung selisih anggaran.

3. Menemukan pos-pos biaya yang dapat dikendalikan dan tidak dapat dikendalikan.

4. Merevisi standar biaya atau target anggaran untuk tahun berikutnya.

Akuntansi Pemerintahan. Sadeli (2015 : 6) menjelaskan bahwa akuntansi pemerintahan termasuk pula akuntansi yang mengkhususkan pada pencatatan dan pelaporan transaksi dari organisasi atau lembaga-lembaga nonprofit seperti: yayasan, mesjid, rumah sakit, lembaga amal, dan lembaga-lembaga pendidikan.

Anggaran Pendapatan dan Belanja Daerah. PP No. 58 Tahun 2005 Pasal 20 tentang Pengelolaan Keuangan Daerah yang menyatakan bahwa APBD adalah satu kesatuan yang terdiri dari: (1) pendapatan daerah; (2) belanja daerah; dan (3) pembiayaan daerah.

Fungsi Anggaran Pendapatan Belanja Daerah. Karianga (2017 : 35) menyatakan APBD memiliki fungsi yang strategis untuk mewujudkan cita-cita kesejahteraan rakyat. 
Siklus Anggaran Pemerintah Daerah. Sujarweni (2015 : 64) Siklus Anggaran Pemerintah Daerah adalah proses/siklus anggaran pemerintah daerah berlangsung selama dua setengah tahun dengan urutan sebagai berikut:

1. Penyusunan dan Penetapan Anggaran.

2. Pelaksanaan Anggaran.

3. Laporan Pertanggungjawaban Pelaksanaan Anggaran

Pedoman Penyusunan APBD Tahun 2017. Peraturan Menteri Dalam Negeri (PERMENDAGRI) No. 31 Tahun 2016. Pedoman tersebut berisi beberapa hal-hal pokok dalam penyusunan APBD yaitu sebagai berikut:

1. Sinkronisasi Kebijakan Pemerintah Daerah Dengan Kebijakan Pemerintah.

2. Prinsip Penyusunan APBD.

3. Kebijakan Umum Penyusunan APBD.

4. Teknis Penyusunan APBD.

Belanja Daerah. Belanja daerah merupakan semua pengeluaran yang mengurangi saldo anggaran lebih dalam periode tahun anggaran bersangkutan dari rekening kas umum daerah yang akan diperoleh pembayaran kembali oleh pemerintah daerah. Belanja daerah terdiri atas belanja tidak langsung dan belanja langsung (Siregar, $2017: 32$ ).

Pelaksanaan Belanja Daerah. Pelaksanaan anggaran belanja daerah yang harus diperhatikan menurut Sujarweni (2015: 68) adalah sebagai berikut:

1. Pengeluaran kas yang menjadi beban APBD sebelum ditetapkan atau dicantumkan dalam lembaran daerah tidak boleh dikeluarkan pengeluran kas tersebut.

2. Dasar pengeluaran belanja untuk keperluan tak terduga yang dianggarkan dalam APBD harus ditetapkan dengan keputusan kepala daerah dan diberitahukan kepada DPRD paling lama satu bulan sejak keputusan tersebut ditetapkan.

3. Pimpinan instansi/lembaga dalam menggunakan dana harus bertanggung jawab dengan menyampaikan laporan realisasi kepada atasan dan kepala daerah.

4. Untuk kelancaran pelaksanaan tugas SKPD, kepada pengguna anggaran/kuasa pengguna anggaran dapat diberikan uang persediaan yang dikelola oleh bendahara pengeluaran.

Belanja Langsung. Permendagri Nomor 13 Tahun 2016 menyatakan kelompok belanja langsung dari suatu kegiatan dibagi menurut jenis belanja yang terdiri dari: (1) Belanja Pegawai; (2) Belanja Barang dan Jasa; dan (3) Belanja Modal.

Efektivitas Belanja Langsung. Mardiasmo (2016 : 85) menjelaskan bahwa efektivitas terkait dengan hubungan antara hasil yang diharapkan dengan hasil yang sesungguhnya dicapai.

$$
\text { Efektifitas }=\frac{\text { Outcome }}{\text { Output }} \times 100 \%
$$

Keputusan Menteri Dalam Negeri Nomor 690.900-327 tahun 1996, menetapkan kriteria tingkat efektivitas anggaran belanja sebagai berikut:

1. Apabila perhitungan perbandingan $>100 \%$, maka kriterianya sangat efektif.

2. Apabila perhitungan pencapaian $90 \%-100 \%$, maka kriterianya efektif.

3. Apabila perhitungan pencapaian $80 \%-90 \%$, maka kriterianya cukup efektif.

4. Apabila perhitungan pencapaian $60 \%-80 \%$, maka kriterianya kurang efektif.

5. Apabila perhitungan pencapaian di bawah $60 \%$, maka kriteriannya tidak efektif.

\section{METODE PENELITIAN}

Jenis Penelitian. Jenis penelitian yang digunakan dalam penelitian ini adalah kualitatif deskriptif di mana penulis secara langsung mendatangi objek penelitian yaitu Biro Hukum Provinsi Sulawesi Utara untuk memperoleh data-data dan informasi yang dibutuhkan 
dengan membandingkan dan menerangkan suatu data atau keadaan agar dapat ditarik suatu kesimpulan dalam menganalisis efektivitas penggunaan anggaran sebagai alat pengendalian belanja langsung.

Tempat dan Waktu Penelitian. Lokasi penelitian yang diteliti penulis bertempat di Biro Hukum Provinsi Sulawesi Utara yang terletak di Kantor Gubernur, JL 17 Agustus, No. 69, Manado, Sulawesi Utara. Waktu penelitian dimulai pada bulan Mei 2018 sampai dengan bulan Juni 2018.

\section{Jenis Data}

1. Data kualitatif yang berupa wawancara dari sumber-sumber yang terkait dalam penelitian ini.

2. Data kuantitatif yakni berupa data Laporan Realisasi Anggaran dan Laporan Pengawasan Anggaran Definitif PerKegiatan yang bersumber dari objek penelitian.

Sumber Data. Sumber data yang digunakan dalam penelitian ini yaitu:

1. Data primer yang didapatkan langsung di tempat penelitian berupa Laporan Realisasi Anggaran (LRA), dokumen lainnya yang berhubungan dengan penelitian, dan hasil wawancara tentang profil objek penelitian, penyusunan anggaran dan penggunaan anggaran kepada Kasubag Tata Usaha, Bendahara, dan Tim Penyusun Anggaran.

2. Data sekunder yang berupa informasi-informasi melalui studi pustaka dengan membaca literatur-literatur yang dapat menunjang penelitian ini.

Metode dan Proses Analisis. Dasar penilaian dari penelitian ini yaitu dengan penyelidikan antara realisasi dengan sasaran yang direncanakan atau dianggarkan. Untuk mengetahui bagaimana penyusunan anggaran belanja langsung di Biro Hukum Provinsi Sulawesi Utara, bagaimana tingkat efektivitas penggunaan anggaran sebagai alat pengendalian belanja langsung di Biro Hukum Provinsi Sulawesi Utara tahun 2015-2017 dan mengetahui faktorfaktor yang mempengaruhi ketidaksesuaian penyerapan anggaran tahun 2015-2017 yaitu sebagai berikut:

1. Tahap pertama: pengumpulan data laporan LRA dan Laporan Definitif Perprogram/kegiatan dan wawancara dengan responden.

2. Tahap kedua: menganalisis penggunaan anggaran tahun 2015-2017 berdasarkan data kuantitatif yang diperoleh dengan menggunakan rumus efektifitas, agar dapat mengetahui sejauh mana tingkat penyerapan dari penggunaan anggaran belanja langsung pada Biro Hukum Sulawesi Utara dan menyajikan jawaban dari hasil wawancara atas masalah yang diangkat dalam penelitian ini. Rumus efektivitas :

$$
\text { Efektifitas }=\frac{\text { Outcome }}{\text { Output }} \times 100 \%
$$

3. Tahap ketiga: pengambilan keputusan.

\section{HASIL PENELITIAN DAN PEMBAHASAN}

\subsection{Hasil Penelitian}

Anggaran Belanja Langsung Biro Hukum Provinsi Sulawesi Utara Sebagai Alat Pengendalian. Biro Hukum Provinsi Sulawesi Utara memiliki beberapa program yang hampir sama dari tahun 2015 sampai dengan tahun 2017. Program-program tersebut memiliki anggaran belanja yang memiliki beberapa kesamaan yaitu terdiri dari belanja pegawai, belanja barang dan jasa serta belanja modal. Pengendalian pada anggaran yaitu membandingkan antara anggaran yang telah ditetapkan dengan realisasinya,dari perbandingan tersebut maka akan diketahui ketidaksesuainan yang terjadi dan perlu dicari penyebabnya. 
Analisis dan perhitungan efektivitas. Efektivitas terkait hubungan antara output dengan tujuan yang memngambarkan kemampuan organisasi dalam melaksanakan program/kegiatan dengan anggaran yang sudah direncanakan dengan target yang sudah ditetapkan. Tingkat efektivitas belanja langsung Biro Hukum Provinsi Sulawesi Utara akan dihitung dari tahun 2015-2017. Dengan dirumuskan sebagai berikut :

$$
\text { Efektifitas }=\frac{\text { Outcome }}{\text { Output }} \times 100 \%
$$

Interpretasi kriteria Efektivitas menurut Menteri Dalam Negeri Nomor 690.900-327 tahun 1996 dapat dilihat pada tabel berikut ini:

Tabel 1. Rasio Efektivitas

\begin{tabular}{lcc}
\hline & Rasio Efektivitas & Kriteria \\
\hline$>100 \%$ & Sangat Efektif \\
$90 \%-100 \%$ & Efektif \\
$80 \%-90 \%$ & Cukup Efektif \\
$60 \%-80 \%$ & Kurang Efektif \\
$60 \%$ & Tidak Efektif \\
\hline
\end{tabular}

Sumber: Menteri Dalam Negeri Nomor 690.900-327 tahun 1996

Analisis Efektivitas Penggunaan Anggaran Belanja Langsung Sebagai Alat Pengendalian Pada Biro Hukum Provinsi Sulawesi Utara Tahun 2015. Tabel 2 menunjukkan bahwa anggaran belanja langsung Biro Hukum Provinsi Sulawesi Utara tahun 2015 dilakukan analisis program-program yang dilaksanakan pada tahun tersebut. Secara keseluruhan, anggaran Biro Hukum tahun 2015 sebesar Rp.4.732.920.000 dengan besarnya realisasi sebesar Rp.4.559.110.868, setelah dihitung tingkat efektivitasnya sebesar 96,33\% dengan kategori efektif, ketidaksesuaian yang terjadi sebesar 3,67\% atau senilai Rp.173.809.132.

Tabel 2. Realisasi Penggunaan Anggaran Belanja Langsung Biro Hukum Provinsi Sulawesi Utara Tahun 2015

(Angka Disajikan Dalam Ribuan 000 Rp)

\begin{tabular}{|c|c|c|c|c|c|c|c|}
\hline \multirow[t]{2}{*}{ No } & \multirow[t]{2}{*}{ Uraian } & \multicolumn{4}{|c|}{$\begin{array}{c}\text { Realisasi Anggaran Belanja Langsung } \\
\text { (Outcome) }\end{array}$} & \multirow[t]{2}{*}{$\begin{array}{c}\text { Target } \\
\text { (output) }\end{array}$} & \multirow[t]{2}{*}{$\begin{array}{l}\text { Efektivitas } \\
(\%)\end{array}$} \\
\hline & & Pegawai & $\begin{array}{l}\text { Barang dan } \\
\text { Jasa }\end{array}$ & Modal & Total & & \\
\hline 1 & $\begin{array}{ll}\text { Program } & \text { Pelayanan }\end{array}$ & 63.600 & 402.600 & 0 & 466.200 .285 & 493.786 .600 & 94,41 \\
\hline 2 & $\begin{array}{l}\text { Administrasi Perkantoran } \\
\text { Program Peningkatan Sarana } \\
\text { dan Prasarana Aparatur }\end{array}$ & 0 & 70.298 & 650.898 & 721.196 .550 & 763.949 & 94,40 \\
\hline 3 & $\begin{array}{l}\text { Program Peningkatan Disiplin } \\
\text { Aparatur }\end{array}$ & 0 & 25.311 & 0 & 25.311 .000 & 25.350 & $\mathbf{9 9 , 8 5}$ \\
\hline 4 & $\begin{array}{lr}\text { Program } & \text { Peningkatan } \\
\text { Pengembangan } & \text { Sistem } \\
\text { Pelaporan Capaian Kinerja dan } \\
\text { Keuangan }\end{array}$ & 36.021 & 12.674 & 0 & 48.695 .875 & 52.808 .400 & 92,21 \\
\hline 5 & $\begin{array}{l}\text { Program } r \text { Peningkatan } \\
\text { Kepastian Hukum Dalam } \\
\text { Penerapan Semua Peraturan } \\
\text { Perundang-Undangan }\end{array}$ & 20.500 & 1.891 .726 & 0 & 1.912.226.258 & 1.939 .692 & $\mathbf{9 8 , 5 8}$ \\
\hline 6 & \begin{tabular}{llr} 
Program & \multicolumn{2}{c}{ Peningkatan } \\
Pelaksanaan & Hak Asasi \\
Manusia & &
\end{tabular} & 23.000 & 337.892 .071 & 0 & 360.892 .071 & 379.137 & 95,19 \\
\hline 7 & $\begin{array}{l}\text { Program Penataan Peraturan } \\
\text { Perundang-Undangan }\end{array}$ & 222.300 & 802.288 .829 & 0 & 1.024.588.829 & 1.078 .197 & 95,03 \\
\hline & Jumlah & 365.421 & 3.542.791 & 650.898 & 4.559.110 & 4.732.920 & 96,33 \\
\hline
\end{tabular}

Sumber: Biro Hukum Provinsi Sulawesi Utara (Data Olahan) 
Analisis Efektivitas Penggunaan Anggaran Belanja Langsung Sebagai Alat Pengendalian Pada Biro Hukum Provinsi Sulawesi Utara Tahun 2016. Tabel 3 menunjukkan bahwa anggaran belanja langsung yang terdiri dari belanja pegawai, belanja barang dan jasa serta belanja modal Biro Hukum Provinsi Sulawesi Utara tahun 2016 dilakukan analisis program-program yang dilaksanakan pada tahun tersebut. Secara keseluruhan, anggaran Biro Hukum tahun 2016 sebesar Rp.5.240.826.000 dengan besarnya realisasi sebesar Rp.5.224.954.949, setelah dihitung tingkat efektivitasnya sebesar 99,70\% dengan kategori efektif, ketidaksesuaian yang terjadi sebesar $0,30 \%$ atau senilai Rp.15.871.051.

Tabel 3. Realisasi Penggunaan Anggaran Belanja Langsung Biro Hukum Provinsi Sulawesi Utara Tahun 2016

(Angka Disajikan Dalam Ribuan 000 Rp)

\begin{tabular}{|c|c|c|c|c|c|c|c|}
\hline \multirow[t]{2}{*}{ No } & \multirow[t]{2}{*}{ Uraian } & \multicolumn{4}{|c|}{$\begin{array}{c}\text { Realisasi Anggaran Belanja Langsung } \\
\text { (Outcome) }\end{array}$} & \multirow[t]{2}{*}{$\begin{array}{l}\text { Target } \\
\text { (output) }\end{array}$} & \multirow[t]{2}{*}{$\begin{array}{c}\text { Efektivitas } \\
(\%)\end{array}$} \\
\hline & & Pegawai & $\begin{array}{l}\text { Barang dan } \\
\text { Jasa }\end{array}$ & Modal & Total & & \\
\hline 1 & $\begin{array}{ll}\text { Program } & \text { Pelayanan } \\
\text { Administrasi } & \\
\text { Perkantoran } & \end{array}$ & 93.900 & 899.688 .410 & 0 & 993.588 .410 & 1.006 .253 .100 & $\mathbf{9 8 , 7 4}$ \\
\hline 2 & $\begin{array}{l}\text { Program Peningkatan } \\
\text { Sarana dan Prasarana } \\
\text { Aparatur }\end{array}$ & 0 & 72.022 .164 & 761.748 .600 & 833.770 .764 & 835.783 .750 & 99,76 \\
\hline 3 & $\begin{array}{l}\text { Program Peningkatan } \\
\text { Disiplin Aparatur }\end{array}$ & 0 & 52.200 & 0 & 52.200 .000 & 52.200 & 100 \\
\hline 4 & $\begin{array}{lr}\text { Program Peningkatan } \\
\text { Pengembangan } & \text { Sistem } \\
\text { Pelaporan } & \text { Capaian } \\
\text { Kinerja dan Keuangan }\end{array}$ & 43.601 & 14.511 .300 & 0 & 58.112 .300 & 58.121 .100 & $\mathbf{9 9 , 9 8}$ \\
\hline 5 & $\begin{array}{l}\text { Program Perencanaan } \\
\text { SKPD }\end{array}$ & 0 & 9.136 .100 & 0 & 9.136 .100 & 9.153 .400 & $\mathbf{9 9 , 8 1}$ \\
\hline 6 & $\begin{array}{lr}\text { Program } & \text { Peningkatan } \\
\text { Kepastian Hukum dalam } \\
\text { Penerapan } & \text { Semua } \\
\text { Peraturan } & \text { Perundang- } \\
\text { Undangan } & \end{array}$ & 0 & 1.323 .840 .650 & 0 & 1.323 .840 .650 & 1.323 .842 .200 & $\mathbf{9 9 , 9 9}$ \\
\hline 7 & $\begin{array}{l}\text { Program Peningkatan } \\
\text { Pelaksanaan Hak Asasi } \\
\text { Manusia }\end{array}$ & 132.800 & 368.207 .125 & 0 & 501.007 .125 & 501.370 .500 & 99,93 \\
\hline 8 & $\begin{array}{lr}\text { Program } & \text { Penataan } \\
\text { Peraturan } & \text { Perundang- } \\
\text { Undangan } & \end{array}$ & 319.000 & 1.134 .299 .600 & 0 & 1.453 .299 .600 & 1.454 .101 .950 & 99,94 \\
\hline & Jumlah & 589.301 & 3.873.905.349 & 761.748 .600 & 5.224.954.949 & 5.240 .826 & $\mathbf{9 9 , 7 0}$ \\
\hline
\end{tabular}

Sumber: Biro Hukum Provinsi Sulawesi Utara (Data Olahan)

Analisis Efektivitas Penggunaan Anggaran Belanja Langsung Sebagai Alat Pengendalian Pada Biro Hukum Provinsi Sulawesi Utara Tahun 2017. Tabel 4 menunjukkan bahwa anggaran belanja langsung Biro Hukum Provinsi Sulawesi Utara tahun 2017 dilakukan analisis program-program yang dilaksanakan pada tahun tersebut. Secara keseluruhan, anggaran Biro Hukum tahun 2017 sebesar Rp.3.218.263.624 dengan besarnya realisasi sebesar Rp.3.210.629.622, setelah dihitung tingkat efektivitasnya sebesar 99,76\% dengan kategori efektif, ketidaksesuaian yang terjadi sebesar $0,24 \%$ atau senilai Rp.7.634.002. 


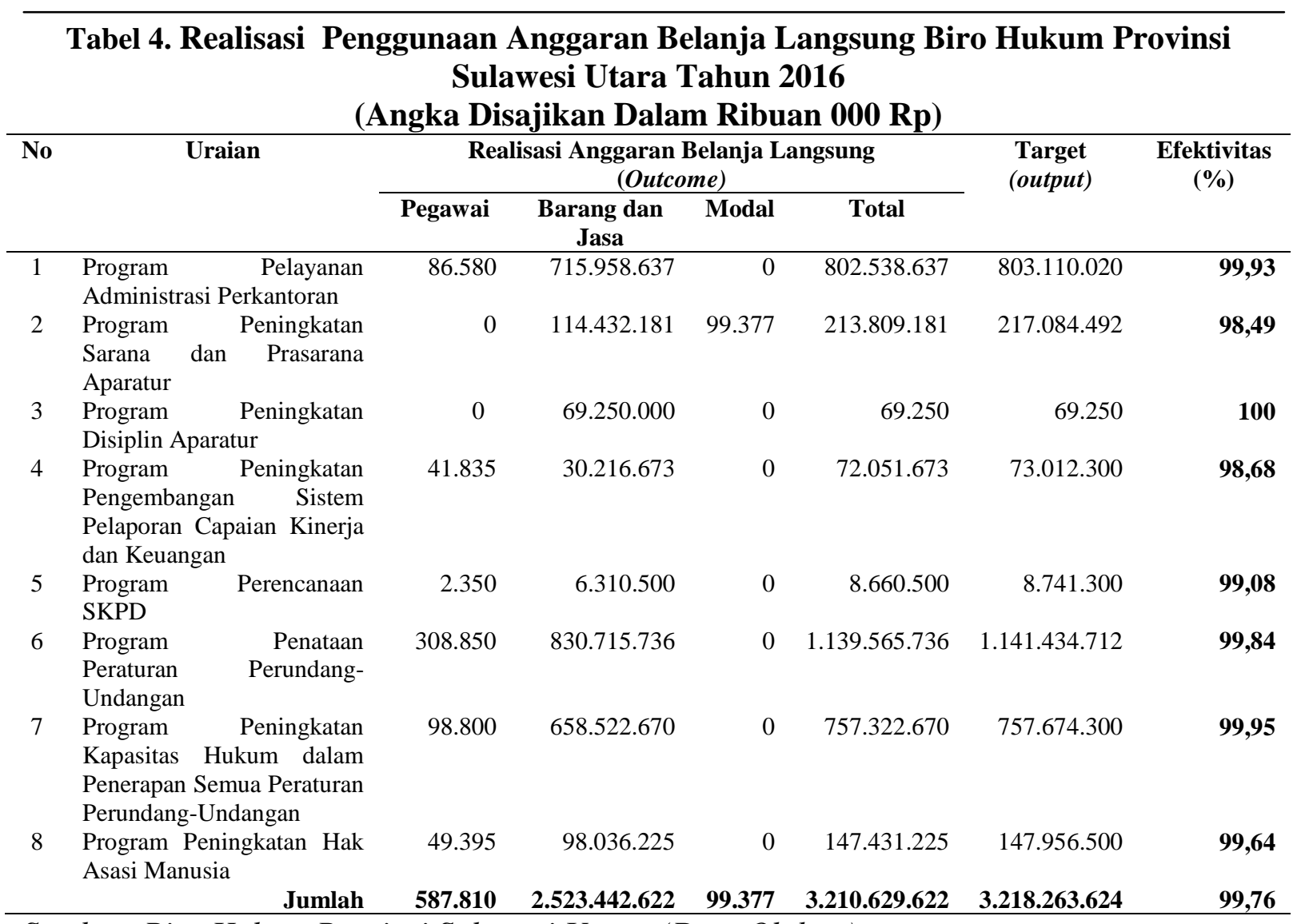

Sumber: Biro Hukum Provinsi Sulawesi Utara (Data Olahan)

\subsection{Pembahasan}

Penyusunan Anggaran Belanja. Penyusunan anggaran belanja pada Biro Hukum Provinsi Sulawesi Utara diawali dengan perencanaan terlebih dahulu. Program kerja dan anggaran merupakan rencana kerja yang menjadi sasaran organisasi untuk pengukuran dan pengendalian. penyusunan anggaran Biro Hukum Sulawesi Utara terdiri dari beberapa tahap yang secara garis besar yaitu: Rencana Kerja Pembangunan, KUA/PPAS, Rencana Kerja dan Anggaran SKPD, dan Rancangan Perda.

Faktor-Faktor Yang Menjadi Bahan Pertimbangan Dalam Penyusunan Anggaran Belanja Langsung Biro Hukum Provinsi Sulawesi Utara. Biro Hukum Provinsi Sulawesi Utara mengatakan bahwa ada 3 faktor utama yang menjadi bahan pertimbangan dalam menyusun anggaran belanja langsung Biro Hukum Provinsi Sulawesi Utara yaitu: rencana kerja, rencana srategi, standar biaya.

Efektivitas Penggunaan Anggaran Belanja Langsung Sebagai Alat Pengendalian Pada Biro Hukum Provinsi Sulawesi Utara Tahun 2015-2017. Anggaran belanja langsung Biro Hukum Provinsi Sulawesi Utara selama periode 2015-2017 rata-rata tingkat efektivitas sebesar 98,60\%. Hasil perhitungan pada tahun 2015 tingkat efektivitas belanja langsung Biro Hukum merupakan tingkat efektivitas terendah dari kurung waktu 2015-2017 yaitu 96,33\% dengan kategori efektif. Kemudian di tahun selanjutnya yaitu 2016 mengalami kenaikan menjadi 99,70\% (efektif). Ditahun 2017 menjadi tahun yang tingkat efektivitasnya tertinggi selama kurung waktu 2015-2017 yaitu 99,76\%. Selama tahun 2015-2017 Biro Hukum memiliki beberapa program yang sudah dijalankannya seperti:

1. Program Pelayanan Administrasi Perkantoran. Program tersebut merupakan program Biro Hukum Provinsi Sulawesi Utara dengan capaian sasaran adalah jumlah pelayanan administrasi perkantoran. 
2. Program Peningkatan Sarana dan Prasarana Aparatur. Program tersebut merupakan program Biro Hukum Provinsi Sulawesi Utara dengan capaian sasaran adalah jumlah pengadaan perlengkapan gedung kantor, pemeliharaan kendaraan dinas operasional.

3. Program Peningkatan Disiplin Aparatur. Program tersebut merupakan program Biro Hukum Provinsi Sulawesi Utara dengan capaian sasaran adalah jumlah pakaian khusus hari-hari tertentu program ini diharapkan hasil (outcome) adalah disiplin aparatur.

4. Program Peningkatan Pengembangan Sistem Pelaporan Capaian Kinerja dan Keuangan. Program tersebut merupakan program Biro Hukum Provinsi Sulawesi Utara dengan capaian sasaran adalah jumlah laporan capaian kinerja dari indikator program diharapkan hasil adalah persentase capaian laporan kinerja seperti penyusunan pelaporan keuangan semesteran, pelaporan keuangan akhir tahun dan penyusunan laporan bulanan SKPD.

5. Program Peningkatan Kepastian Hukum dalam Penerapan semua Peraturan PerundangUndangan. Program tersebut merupakan program Biro Hukum Provinsi Sulawesi Utara dengan capaian sasaran adalah banyak masalah/Kasus yang dapat diselesaikan dan peningkatan kesadaran hukum dikalangan masyarakat.

6. Program Perencanaan SKPD. Program perencanaan SKPD merupakan program Biro Hukum Provinsi Sulawesi Utara dengan capaian sasaran adalah penyusunan rencana strategi SKPD, penyusunan rencana kerja SKPD dan penyusunan rencana kerja anggaran.

7. Program Peningkatan Pelaksanaan Hak Asasi Manusia. Program tersebut mempunyai capaian sasaran adalah meningkatkan pelaksanaan jejaringan organisasi dan lembaga di bidang HAM, pemberian penghargaan desa sadar hukum, meningkatkan sosialisasi, edukasi dan pelatihan di bidang penegakan HAM.

8. Program Penataan Peraturan Perundang-Undangan. Program tersebut merupakan program Biro Hukum Provinsi Sulawesi Utara dengan capaian sasaran tersedianya produk hukum daerah, sosialisasi dan penyuluhan hukum terpadu, bimbingan teknis jaringan dokumentasi dan informasi hukum nasional dan lain-lain.

Faktor-Faktor Ketidaksesuaian Penyerapan Anggaran Belanja Langsung Pada Biro Hukum Provinsi Sulawesi Utara Tahun 2015-2017. Ketidaksesuaian anggaran yang terjadi pada Biro Hukum Provinsi Sulawesi Utara tahun 2015-2017 diakibatkan oleh penghemat anggaran yang merupakan akumulasi dari jenis-jenis belanja yang tidak diperlukan, adanya nilai sisa dari pembelanjaan, perbedaan harga pasar dari harga yang sudah dianggarkan oleh Biro Hukum Provinsi Sulawesi Utara dan terkhususnya tahun 2015 disebabkan oleh program peningkatan sarana dan prasarana aparatur yang di mana untuk kegiatan pemeliharaan rutin kendaraan tidak terealisasi semua dikarenakan adanya kendaraan dinas yang sudah dimutasi dan dilelang.

\section{KESIMPULAN DAN SARAN}

\subsection{Kesimpulan}

1. Proses penyusunan anggaran belanja pada Biro Hukum Provinsi Sulawesi Utara sudah sesuai dengan prosedur yang ditetapkan Yang adapun rincian dari tahapan yang sesuai yaitu menyinkronisasi kebijakan kepala daerah dengan pemerintah melalui RKPD, selanjutnya menyusun KUA dan PPAS yang dievaluasi dan diserahkan oleh DPRD, SKPD menyusun RKA SKPD dan selanjutnya dibuat Perda, kemudian menetapkan Perda tentang APBD.

2. Anggaran belanja langsung tahun 2015-2017 pada Biro Hukum Provinsi Sulawesi Utara tingkat efektivitas selama tahun tersebut tidaklah sama yang di mana tahun 2015 sebesar 96,33\% tahun 2015 ini merupakan tahun yang penyerapan anggaran terendah dari ketiga tahun tersebut tetapi masih dalam kategori efektif. Tingkat efektivitas pada tahun 2016 yaitu sebesar 99,70\% dan tahun 2017 sebesar 99,76\%. Yang di mana selama tahun 2015- 
2017 dikatakan spending wisely dikarenakan program dan kegiatan dinilai efektif dikarenakan output yang dihasilkan mencapai tujuan.

3. Faktor-faktor yang mempengaruhi ketidaksesuaian penyerapan anggaran pada Biro Hukum Provinsi Sulawesi Utara tahun anggaran 2015-2017 diakibatkan oleh penghemat anggaran adanya nilai sisa dari pembelanjaan, perbedaan harga pasar dari harga yang sudah dianggarkan oleh Biro Hukum Provinsi Sulawesi Utara dan juga untuk tahun anggaran 2015 menjadi tingkat penyerapan yang paling rendah dikarenakan kegiatan pemeliharaan rutin kendaraan tidak terealisasi semua dikarenakan adanya kendaraan dinas yang sudah dimutasi dan dilelang.

\subsection{Saran}

Berdasarkan kesimpulan di atas maka penulis memberikan saran kepada Biro Hukum Provinsi Sulawesi Utara bahwa dalam penyusunan anggaran belanja harus tetap dipertahankan karena sudah sesuai dengan pedoman. Serta untuk faktor-faktor pertimbangan penyusunan anggaran belanja kiranya perencanaan menjadi hal yang penting agar anggaran dapat digunakan sesuai dengan yang direncanakan sehingga penyerapan anggaran berjalan dengan baik dan kiranya dibuat standar harga pasar agar tidak terdapat selisih antara harga satuan pasar dengan harga satuan yang dianggarkan oleh Biro Hukum Provinsi Sulawesi Utara.

\section{DAFTAR PUSTAKA}

Haruman, Tendi. 2013. Penyusunan Anggaran Perusahaan. Graha Ilmu. Yogyakarta.

Hutauruk, Martinus. 2017. Akuntansi Perusahaan Dagang. Edisi 1. UPP STIM YKPN. Yogyakarta.

Karianga, Hendra. 2017. Carut Marut Pengelolaan Keuangan Daerah Di Era Otonomi Daerah Perspektif Hukum dan Politik. Prenada Media. Jakarta.

Keputusan Menteri Dalam Negeri Nomor 690.900-327 Tahun 1996 tentang Pedoman Penilaian dan Kinerja Keuangan.

Mardiasmo. 2016. Akuntansi Sektor Publik. Edisi III. Andi. Yogyakarta.

Peraturan Menteri Dalam Negeri No. 13 Tahun 2016 Tentang Keuangan Daerah.

Peraturan Menteri Dalam Negeri No. 31 Tahun 2016 Tentang Pedoman Penyusunan Anggaran Pendapatan dan Belanja Daerah Tahun Anggaran 2017.

Peraturan Pemerintah Nomor 58 Tahun 2005 Tentang Pengelolaan Keuangan Daerah.

Sadeli, Lili M. 2015. Accounting Theory. Edisi 5. Salemba Empat. Jakarta.

Siregar, Baldric. 2017. Akuntansi Sektor Publik: Akuntansi Keuangan Pemerintahan Daerah Berbasis Akrual. Edisi II. UPP STIM YKPN. Yogyakarta.

Sujarweni, V. Wiratna. 2015. Akuntansi Sektor Publik. Pustaka Baru. Yogyakarta.

Windari, Ayu. 2015. Analisis Kinerja Anggaran Belanja Pada Badan Perencanaan Pembangunan Daerah (BAPPEDA) Kota Palembang. Skripsi. Universitas IBA Palembang. 